\title{
The Political Economy of Nigeria's Power Sector Reforms: Challenges and Prospects, 2005-2015
}

\author{
Gerald Ezirim, Ph.D \\ Department of Political Science, University of Nigeria, Nsukka, Nigeria \\ Onyemaechi Eke, Ph.D
}

National Examinations Council, Minna, Niger State, Nigeria

Freedom Onuoha, Ph.D

Research Fellow, National Defence College, Abuja, Nigeria

\section{Doi:10.5901/mjss.2016.v7n4p}

\begin{abstract}
The availability of power is an inexorable catalyst to boost levels of industrial activity for economic development. Nigeria's electricity supply is dismal owing to institutional, legal, regulatory and capital problems. With a large population, the abysmal generation of less than 4,500 megawatts of electricity hardly suffices for energy requirements. Government's capital-intensive holistic reform of the sector for reliable service delivery with huge production target has been inadequate. The paper unveils the challenges and prospects of the reforms and its strategic implications for Nigeria's socio-economic development. It identifies blatant corruption, lack of political will and international best practices as hampering success. It recommends that effective and efficient management of power supply will increase industrialisation, private and public participation, job creation, high productivity and redirection of youthful energies into productive forces to bring about national development.
\end{abstract}

Keywords: Nigeria, political economy, power sector reforms, energy, electricity, megawatts.

\section{Introduction}

The Nigerian power sector is primarily responsible for generating electricity for the country's industrial activities to boost economic development. Right from the colonial era, the sector has remained strategically important and has continued to attract massive financial investments from government. The First National Development Plan considered electricity as a priority with second ranking in allocation of $14.8 \%$ after $21.7 \%$ for transport. Regrettably, the sector is characterised by crisis of ineptitude and perceptional errors of the monopolistic government provider as social- rather than economicdriven enterprise. The problems orchestrated by epileptic power supply to industrialists and multinational corporations, for example, have forced many companies out from Nigeria to nearby Ghana, where power is more stable (Ezeani, 2008). Thus, many policy steps have been designed and implemented to reposition Nigeria's energy sector but it has remained ailing, attracting national and international concern and support. Nigeria's National Assembly, in an effort to contribute in revitalising the sector, has not only carried out investigations on the sector but also tried to articulate power sector reform and ways of energizing the sector into efficient and competitive electricity industry, which provides a continuous supply of electricity to consumers at an affordable price (Federal Ministry of Information, n.d.). Thus, the National Assembly sponsored a bill mandating oil companies registered in Nigeria to pay $2 \%$ of their profit for improving energy sector in the country (Salem, 2010).

The sector draws sympathy and assistance also from many international bodies like the World Bank and African Development Bank. All the efforts to revitalise the sector seemed to have gone into drain-pipes such that the government in 2000 formulated and approved a power policy in 2001 to kick-start the reform. Thus, the Electric Power Sector Reform Bill was passed in February 2005 and signed into law as the Electric Power Sector Reform Act (EPSRA) by President Obasanjo on 11 March 2005. The EPSRA repealed the National Electric Power Authority (NEPA) and the Electricity Act. It provided the legal backing for the reform process. These efforts worsened the collective anxiety of many informed Nigerians as over $\$ 10 \mathrm{bn}$ was spent by the regime without commensurate result (Akomolafe, 2013).

The reform aimed at removing the encumbrances of NEPA and transforming the Nigerian sole electricity provider 
into a more efficiently managed sector. The direction of the power sector reform was expected to open the opportunity for the development of small and medium scale enterprises; bridge migration from rural to urban cities to access electricity in processing farm produce; remove incessant carnage caused by candle lights and generators; and create job opportunities for Nigerian teeming graduates.

On assumption of office in 2007, President Yar'Adua stepped up the reform in compliance with the objectives of the EPSRA 2005, to improve energy production, transmission and distribution; beginning by declaring emergency in the sector in order to move power production from its abysmally low to higher level that would serve Nigeria's energy need for economic development.

Shortly after taking over power, President Jonathan in August 2010 initiated a roadmap for the reform of the sector. The plan projected that $5,379 \mathrm{mw}$ would be generated by December 2011 and increase to $15,000 \mathrm{mw}$ by 2014 subject to adequate funding. However, this has not been the case as there is miserably inadequate generation, inefficient transmission, and inefficient distribution attributed to poor funding. But it is evidentially established that year-in year-out, tonnes of money in just about every major currency is allocated to (although not necessarily spent on) the power sector (The Guardian, 24 June, 2013). The Jonathan administration's policy drive was to privatize the power plants for effective electricity generation and transmission through the National Integrated Power Projects (NIPP). The project yielded dividends as power plants were privatized and commissioned, and management staff of PHCN were demobilized and competent ones re-absorbed in the new arrangement. This action gave some level of confidence to investors in the sector. It is against this background that the study seeks to unravel the challenges and prospects in the reform package to boost Nigeria's economic activity, infrastural development and general well-being of the Nigerian people.

\section{Objectives of Nigeria's Power Sector Reforms}

The importance of electricity for productive capacity of any nation, the low-level of Nigeria's industrial productive capacity, the ever-growing population and attendant low per capita consumption of electricity comparative to other countries of the world; its constraint on economic activity of the citizens and, by extension, its undermining effects on Nigeria's industrial takeoff for decades, cumulatively informed the need for the power sector reform. NEPA had over the years given Nigerians epileptic and poor quality service. It could not sustain itself as it depended on government's massive subvention with only about $50 \%$ of Nigerians accessing electricity at only about $50 \%$ of the total installed capacity of $6,000 \mathrm{mw}$ from eight power stations. The unrealisability of the installed capacity resulting from decaying infrastructures made supplies grossly inadequate for the country's 160 million population. Thus, the power sector reform, according to FRN (2005) was basically informed by the following considerations:

- Creation of an initial holding company into which NEPA assets, liabilities and staff would be transferred and the subsequent unbundling of that initial holding company. The initial holding company was thus set up and was called Power Holding Company of Nigeria (PHCN);

- Incorporation of successor companies and the privatisation of the unbundling entities: Bureau for Public Enterprises (BPE) appointed a legal firm to set up the companies;

- Establishment of a regulatory agency: Nigerian Electricity Regulatory Commission (NERC) by the BPE;

- Establishment of a Rural Electrification Agency (REA) and funding of the EPSRA: The EPSRA Act established the REA and BPE consultants would assist in the physical establishment of the agency, which would manage the fund to be used to provide financial support for rural electrification projects; and

- Establishment of Power Consumer Assistance Fund: NERC was expected to manage this fund, which would be used to subsidise under-privileged power consumers.

Deriving from the objectives of the Act, the reform focused on three broad principal goals, to:

- Improve power supply for domestic, commercial and industrial users;

- Attract private investment to complement funding by government for the expansion of electricity services to all parts of the country; and

- Ensure that electricity supply is made more reliable, economically efficient and equitable to effectively support Nigeria's socio-economic development (FRN, 2005).

Based on the low electric power generation, transmission and distribution despite huge sums of money expended on the sector by the Obasanjo administration, Yar'Adua was determined to lift the production capacity of Nigeria's power stations beyond $4,000 \mathrm{mw}$ which Obasanjo left it in 2007. To carry out reform, the government avoided total privatisation of the sector with strategic reserve control by government of the transmission aspect while leaving generation and distribution to private participation. Government's handling of the transmission segment was expected to add strategic 
value to the evolving national gas master plan.

The International Energy Institute's comparative analysis of per capita consumption of electricity worldwide, places Nigeria as a relative back-bencher, stating:

In the Americas (North and South) the U.S. with a population of $250 \mathrm{~m}$ generates $813,000 \mathrm{mw}$ with a per capita consumption of $3.2 \mathrm{kw}$ while Cuba with a population of $10.54 \mathrm{~m}$ generates $4,000 \mathrm{mw}$ and a per capita consumption of $0.38 \mathrm{kw}$. In Europe, the U.K. with a population of $57.5 \mathrm{~m}$ generates $76,000 \mathrm{mw}$ with a $1.33 \mathrm{kw}$ per capita consumption while Ukraine in Eastern Europe with $49 \mathrm{~m}$ people generates $54,000 \mathrm{mw}$ and has a $1.33 \mathrm{kw}$ per capita consumption. In the Middle East and Far East, Iraq with $23.6 \mathrm{~m}$ inhabitants generates $10,000 \mathrm{mw}$ with a 0.42 per capita consumption and South Korea generates $52,000 \mathrm{mw}$ with a population of $47 \mathrm{~m}$ and has a $1.09 \mathrm{kw}$ per capita consumption. In Africa, Nigeria with a population $150 \mathrm{~m}$ generates below $4,000 \mathrm{mw}$ with a $0.03 \mathrm{kw}$ per capita consumption; Egypt with a population of $67.9 \mathrm{~m}$ generates $18,000 \mathrm{mw}$ and has a $0.256 \mathrm{kw}$ per capita consumption while South Africa's $1.015 \mathrm{kw}$ per capita consumption derives from $45,000 \mathrm{mw}$ generation for a population of $44.3 \mathrm{~m}$ (FMI, n.d).

The above illuminates the sad story of Nigeria's power sector despite her generous gift of oil-capital to realize a reliable power supply to the population's economic activity at more accessible and affordable price.

\section{Theoretical Framework}

This paper employs the Marxian post-colonial state theory as the explanatory tool of analysis as post-colonial tendencies have shaped the character and nature of the Nigerian State, its politics and policies. As explained by Alavi (1972),

The argument is premised on the historical specificity of post-colonial societies, a specificity which arises from structural changes brought about by the colonial experience and alignments of classes and by the superstructures of political and administrative institutions which were established in that context, and secondly from radical re-alignments of class forces which have been brought about in the post-colonial situation.

Thus, it was in order to secure their economic interests that colonial governments discouraged the emergence of a strong indigenous capitalist class. The specific manner in which the colonialists produced the indigenous elite turned the competition for the control of state power into a do-or-die affair hinged on corrupt practices and inefficient service delivery. This was so because control of state power provided the only access to primitive accumulation of capital - the process by which a class of capitalists are produced. Consequently, state institutions became the main instruments for perpetuation of class interests and for wilful alienation and self-reproduction.

Furthermore, the feature of the socio-economic formation in post-colonial states, and indeed in contemporary peripheral formations generally, is that the state has very limited autonomy (Alavi, 1972). That is, the state is institutionally constituted in such a way that it enjoys limited independence from the social classes - particularly the hegemonic social class - and so is immersed in class struggle instead of rising above it. This is why the post-colonial state is incapable of mediating the class struggle. The Nigerian state is no different in class struggle and economic competition. This vividly explains why the power sector reforms have continually been a struggle for government to deal with despite all the efforts that had been going on in the sector since Nigeria's independence. Those who have benefitted from the inadequate power supply have ensured that successful reforms never take place. This is because of the weak economic base of the class that inherited post-colonial Nigeria, which has made the state a major instrument of investment and development of personal-regarding interests, thereby making the class wholly reliant on the state for wealth accumulation.

This framework of analysis helps in understanding how the instrumentalist nature of the Nigerian state constitutes to the state of inefficient service delivery in the power sector and the resultant effects of this disaggregated action on the citizenry and the Nigerian economy generally.

\section{Challenges to Nigeria's Power Sector}

Nigeria has been unable to manage her human and natural resources in the productive sector to bring about development and growth in her economy for the specific objective to sustain her ever-growing population. NERC revealed that Nigerians spend up to N769.4bn annually in fueling generators for electricity. Of this amount, N540.9bn is spent on diesel-powered generators, while N255.5bn is for buying petrol for generators. NERC contended that because of the erratic power supply, the Nigerian Presidency appropriates N2bn for the purchase, maintenance and fueling of the generators that service the Presidential villa (House of Reps Committee on Power, 2009). Akaeze (2009) re-enacts the parlous state of the power sector when he revealed:

Nigeria tops the list of generator-importing countries for four successive years having surpassed other countries 
since 2002. Similarly, the country accounted for 35\% representing $\$ 152 \mathrm{~m}$ of the total sum of $\$ 432.2 \mathrm{~m}$ spent by other African countries on generator importation. The figure has increased by another $20 \%$ in the past two years due to the worsening power situation in the country.

Akaeze (2009) maintained that a total of 750 companies representing $30 \%$ of companies operating in Nigeria either relocated to nearby countries like Ghana or closed down completely in 2006 due to electricity failure which for many years brought the GDP from 8.2\% high in 1990 to $4.2 \%$ low in 2011. Aside from that, the UNDP put Nigeria's economic losses as a result of absence of constant electricity supply at about N66bn per year. The constraint posed by inadequate power supply to small scale enterprises is such that as much as $20-30 \%$ of the never-ready capital is wasted as initial investment on the acquisition of facilities to enhance electricity supply reliability thereby occasioning significant negative impact on costs competitiveness of the manufacturing sector (Okpugie, 2009).

Analysts have tried to identify the problems of the sector and proffer ways to solving them. The Nigerian Presidential Reform Committee identified insufficient power generation infrastructure, poor maintenance culture, inadequate funding, gas shortage, obsolete equipment, weak and inadequate network coverage and sub-standard distribution lines, as major obstacles against improved electricity supply to consumers (Ejumudo \& Ejumudo, 2014). All the enumerated problems by the Committee constituted cogs on the first bait of privatisation as a conditio sine qua non for the reform process. The Committee also identified the challenges of poor billing system and customer relations of the $\mathrm{PHCN}$, for example, PHCN's record of $\$ 4.06 \mathrm{bn}$ only as income for eight-year period (Lawal \& Ebosele, 2008). There is also the associated criminal practice of PHCN officials to incessantly orchestrate vindictive power outages to extort private reconnection fees. The billing system has become a conduit pipe to defraud unsuspecting victims and reward friends and accomplices through estimated bills. Government officials and agencies deliberately delay payment of electricity tariffs, which result to bad debt syndrome that plague the operation and financial viability of PHCN (AhiumaYoung, 2009). More so, appointments in the sector have taken the path of settling political scores by the use of carrot and stick approaches against friends and foes, respectively, to the detriment of professionals and/or the public that is forced to pay the price of cut-throat sharp practices of the monopolistic government enterprise. The World Bank/UNDP report succinctly stated that "there has been much misuse of National Electric Power as a political patronage machine in terms of staffing and employment policies, through unrealistically low tariffs and as a source of large, lucrative construction contracts" (Ukpevo, 1993).

Related to that is the presence of bureaucratic schism and delays over role differentiation and the appropriate agency among the many (Ministry of Energy, NERC, NIPP, REA, PHCN) to administer the fund for implementing the reform in the sector. The imbroglio between the Ministry of Power and Steel and NERC over which among them would manage the Federal Government allocated N177.95bn for the revival of the sector is quite elucidating (Oloja, 2009).

The bureaucratic scramble recreates the critical problem of dearth of funds to revitalise the sector. Nicholis (2007) revealed that Nigeria needs about $\$ 60 \mathrm{bn}$ to resuscitate the power sector from lack of vocational skills and breakdown of infrastructure to end power outage in the country. Ogbodo and Yakubu (2008) add that should Nigeria's power stations be revitalised at full capacity energy production with an estimated N80b, they cannot wholly address the country's energy problems. He maintained that:

Shiroro power station needed about N145m for maintenance in 2008 and additional N62bn in the five-year development plan; Delta power station needed N8bn to make its five-year development plan a reality; Kainji power station required N1.5bn; Afam power station also required N1bn; Egbin power station needed N7.23bn; and Jebba required N398m.

The disturbing trend was that Jebba hydro power plant was producing $270 \mathrm{mw}$ from its full capacity level of 5784mw; Shiroro, $300 \mathrm{mw}$ from 600mw; Kainji, $580 \mathrm{mw}$ from 760mw; Afam thermal station, $200 \mathrm{mw}$ from 969mw; Delta station, 400mw from 900mw; Geregu power station, $90 \mathrm{mw}$ from $414 \mathrm{mw}$; Sapele, $170 \mathrm{mw}$ from installed capacity production of 1020mw (Igbikiowubo, 2007; Okpugie, 2009).

It is, however, to be noted that adequate power generation alone without addressing transmission challenges would not solve the problems of the sector. Thus, the Chief Economic Adviser to President Yar'Adua, Tanimu Yakubu, revealed that Nigeria needs an estimated N117bn to establish three central processing facilities for gas production which are to be located in the Niger Delta in order to be able to process upstream gas, extract liquefied petroleum gas and transmit dry gas to the domestic market (The Guardian, July 21, 2008).

The perennial convulsion in the power sector in Nigeria attracted worse criticisms by commercial and residential electricity consumers, who expressed anxiety over the country's capability to sustain adequate electricity generation at pre-1999 levels of 1,520mw, not to talk of guaranteeing improved, uninterrupted power supply. The worries followed government's acclaimed expenditure of billions of naira; several power generation projects across the country to augment power generation in the system through the independent power project arrangement. The scenario inevitably created a 
disconnect with the aspirations and developmental needs of citizens in the $21^{\text {st }}$ century technologically- and knowledgedriven interdependent global system.

Despite the despicable scenario in the power sector, the then Minister for Power, Ahmed Abdulhamid euphorically told Nigerians that from the poor total of 2,000mw, Nigeria's electricity generation was increased to $3,300 \mathrm{mw}$ by April 2007 based on federal government's renewed emphasis on the power sector even though Edmund Daukoru had admitted that based on gas supply shortage to the 1,320mw capacity Egbin thermal power plant in Ikorodu, as a result of vandalisation of the Escravos-Lagos pipelines, power supply in the country had drastically dropped. However, sounding optimistic, Daukoru insisted that despite the worsening electricity supply situation, the Obasanjo administration would achieve a set target of 5,500 mw by 29 May 2007 when it would hand over to an in-coming regime that was expected to increase power generation to $10,000 \mathrm{mw}$ by 2010 . This was premised on the fact that with estimated power production from the proposed power plants and the existing ones (Jebba 574.5mw; Shiroro 600mw; Egbin 1,320; Kainji 760mw; Geregu 414mw; Afam 969; Mambila 2,600mw; Okpai 480mw; Omoku 230mw; Omotosho 335mw; Papalanto 335mw; Alaoji 1,074mw; Gbaran 225mw; Ihovbor 451mw; Sapele 451mw; Egbema 338; Calabar 561mw; Ibom 188mw, the Katsina wind-project, etc), there would be increased power generation and supply to make up the proposed target of $10,000 \mathrm{mw}$ by 2010 . However, he did not reconcile the dwindling power generation to the bad shapes of the power stations with his ambitious expectations.

More so, optimists and apologists of the Obasanjo administration failed to reconcile the administration's unrealised target of $10,000 \mathrm{mw}$ in 2005 to pave way for meeting $20,000 \mathrm{mw}$ target in 2010 as the condition for budgeting the whopping sum of $\$ 15 \mathrm{bn}$. The disturbing contradiction was that the budgeted sum was allegedly exceeded when the sector was yet to realise mere $3000 \mathrm{mw}$ in spite of the power purchase arrangement which yielded to the IPP projects in the country. Again, while the $\$ 10$ billion West African Power Pool (WAPP) target was about 28,000mw (The Guardian, October 3, 2001), Nigeria spent about \$15bn without significant increase to the nation's 4,000mw or thereabouts.

Situating the expected 5,500mw generation side by side with the Yar'Adua administration's admission of about $4,040 \mathrm{mw}(2,666 \mathrm{mw}$ from thermal stations and 1,380mw of hydro-power stations) and the yet expected 1,000mw from various independent power stations as at 2009, it becomes more worrisome that Nigerians were being deceived through phony statistics to rationalise the huge expenditure on the ailing power sector. As a matter of fact, as at September 2012, the figure was 4,439.5mw (Ofikhenua, 2012).

There is also the challenge of inexorable nexus between power generation, transmission and distribution. The connexion is that electrical current generated from the power stations is boosted and transmitted through Extra High Tension (EHT) lines as pylons running to consumer areas, where it is stepped down to 410/240 volts. The problem of transmission is related to the nature of heat maintenance over a long distance. According to Enisuoh, cited in Okpugie (2009), "electricity current potency is equal to force multiplied by distance." Applied to electric current passing over a long distance, it is estimated that up to 500 kilo-volts can be lost over a distance of between $450 \mathrm{~km}$ to $1,000 \mathrm{~km}$. The situation can be addressed through strategic policy of establishing multiple environmentally-friendly and technically feasible power stations that are closer to the major sources of consumption, such as cities and industrial areas. The policy-steps rationalises the demand for Independent Power Projects (IPPs) in order to relieve government of the financial stress in a competitive, efficient and effective manner.

Also, power generated could be hampered at the distribution stage by low gas supply. Salau (2010) reports that to boost Nigeria's 6,000mw capacity power stations from her estimated 182 trillion cubic feet gas reserves, she needs only 523 million standard cubic feet per day (scfpd) for the western area (including about 150mscfpd, earmarked for industries and West African Gas Pipeline) and eastern parts requires 197mscfpd. For instance, Nigeria's Utorogu gas plant with production capacity of 310mscfpd, could supply Egbin plant with only 103scf; Sapele and Ughelli gas plants with a capacity for 50mscf were not producing gas; Oben gas plant with a capacity to produce $90 \mathrm{~m}$ scf, which serves Geregu was known to be generating far lower than its installed capacity; the only exception, at the time, was Okoloma, which had been meeting the 100mscf gas requirement of Afam 6 (Obasi, 2009). Thus, it was revealed that out of 750mscf rquired for the distribution of mere $2,666 \mathrm{mw}$ of electricity generated from the thermal stations, only about $230 \mathrm{~m}$ scf was produced to force out between 2,500 and $2,800 \mathrm{mw}$ per day.

The challenges appear even more critical at the very low generating capacity for a thickly populated country like Nigeria that is energy resource rich that could not meet her energy demand of about 25,000mw when compared to other energy resource limited and less populated countries that have far more energy generation. Affirming the assertion in the debate, Owubokiri in Igbikiowubo (2001) stated:

Nigeria is an energy resource rich country which shouldn't be going through the current energy crisis...South Africa, despite its resource limitations, generates $45,000 \mathrm{mw}$ of electricity for 40 million people ... Austrian government generates over 100,000 mw for a population of three million inhabitants in Vienna alone. 
The relationship between electricity and political empowerment is quite obvious and insightful of countries' generated power output, GDP and per capita income. While GDP and per capita income are indices of a country's prosperity and its people's standard of living, these indices are directly proportional to the country's generated output (Oke, 2010). This is the rationale behind Nigerian government's launch of her first nuclear energy satellite with the expectation of generating additional 1,000mw to the national grid under the country's Vision 20:2020 programme (The Guardian, March 1, 2009). In a comparative analysis of countries' GDP and per capita income to illustrate Nigeria's poor position among 10 most industrialised nations of the world, Oke (2010) wrote:

...information from the World Bank and U.S. Energy Information Administration puts the GDP and per capita income of the U.S. in 2009 at $\$ 46,436$ and $\$ 42,240$. For the preceding year, the generated power output of the U.S. was 4,116.981bn kw hours. For Canada, the same figures were $\$ 39,599, \$ 42,170$ and $612.227 \mathrm{bn}$ kw hours. For France, they were $\$ 42,312, \$ 43,990$ and $540.259 \mathrm{bn}$ kw hours. For Germany, they were $\$ 40,873, \$ 42,560$ and 590.208 billion kw hours. For Japan, they were $\$ 39,727, \$ 37,870$ and1,015.219bn kw hours. Italy had $\$ 35,084, \$ 35,080$ and $292.580 \mathrm{bn} \mathrm{kw}$ hours. Russia also had $\$ 8,676, \$ 9,370$ and $982.999 \mathrm{bn}$ kw hours. Then, Nigeria poorly had $\$ 1,092, \$ 1,140.00$ and $\$ 1.109 \mathrm{bn}$ kw hours...

Igbikiowubo (2007) reported that in Nigeria's fourteen-month power outage:

No metropolis in the country; from Kano to Port Harcourt and Lagos to Calabar, including the Federal Capital Territory was spared the season of anomie. Spending on fuel to power electricity generating sets increased astronomically without a corresponding increase in income levels. Noise pollution, as well as carbon emission levels increased, heightening the threat to health and living standards of the average Nigerian. Despite the development, electricity bills from the PHCN are administered on hapless power supply consumers without a corresponding reflection on the impact the lack of electricity supply should have on the bills. Efforts to quantify spending on fuel to power electricity generating sets continue to pose enormous logistic challenges and the resultant loss of man-hour and industrial output to the national economy occasioned by the lack of power supply from the public utility company is simply incalculable.

The ineffective, inefficient and uncompetitive power generation, transmission and distribution in Nigeria has been attributed to related challenges of transparency and accountability, which have dealt a very serious blow on the socioeconomic life of the nation and her citizens.

\section{Related Challenges of Efficiency, Transparency and Accountability}

The major challenges of the power sector are related issues of management efficiency, transparency and accountability. These reinforce the contention of the IMF as reported by Olajide (2008) that viability, efficiency and effectiveness of the sector depend on related issues of transparency and accountability, which also depend on solid financial management, procurement and management information system to put the sector on a positive trajectory of improved sector and utility management, financial viability, new investment and better customer service with further development of generation capacity based on natural gas. Realizing the challenge paucity of funds post to Nigeria's power sector, the IMF counselled, "capital is more likely to be forthcoming in an environment where tariff structure, power purchase agreement and reliable transmission interconnections have been addressed" (Olajide, 2008). The poser requires Nigeria to adopt international best practices through the culture of business-friendliness devoid of policy instability and corruption, among other vices.

Most importantly, NERC which was established to implement Nigeria's power sector reform programme, soon became bedeviled by allegations of massive corruption and sharp practices against the public interest it was established to defend. The stench of award of contracts for consultancy services without recourse to due process filled the air; NERC was alleged to have failed to comply with Federal Treasury circulars on fixed deposit account, unclaimed salaries, wages, unspent balance of voted expenditures; closure of end of year account; and violation of federal-approved estacode limits per night for officers (Agbaegbu \& Adzegeh, 2009).

Truly, most Nigerian leaders in positions of authority cannot be trusted to change for the better. This is why the direct involvement of both the late President Yar'Adua and his successor, Jonathan, to monitor and direct the affairs in revamping the power sector elicits not only political will but also manifest responsibility with the attached transparency and accountability.

It was on the premise of Obasanjo administration's boast of service to the nation and expenditure in billions of naira without commensurate results that gave rise to the mandate of the House of Representatives Committee on Power and Steel to investigate alleged \$10bn expenditure by the administration in the power sector between April 1999 and June 2007. The then Minister of Energy, Ahmed Abdulhamid, had stated that Nigeria was generating about 3,300mw, which started when the Nigeria Gas Company completed the cleaning of gas pipelines, and that with the commissioning 
of the Omotosho Gas Turbine, a lot of improvement has come into the system.

However, Presidential Adviser on Power, Joseph Makoju, stated that Obasanjo had commissioned several power stations, including Omoku (150mw), Geregu (414mw), Omotosho (335mw) and Alaoji (504mw) capacity, respectively. He claimed that more plants would be commissioned before the end of 2007 as a measure to achieve the 10,000mw target set by the administration (Yakubu, 2007).

Earlier during the commissioning of the Omotosho gas turbine, President Obasanjo had stated that the commissioning of the Papalanto thermal power station in Ogun State would improve Nigeria's power situation and that his administration had laid the foundation of the Mambila 2,600mw capacity hydro-power station, which was started with feasibility studies since the 1950s. Obasanjo's administration also touted it had through approval of $\$ 3 \mathrm{~b}$ intervention fund by National Economic Council of Nigeria prepared the way for additional Greenfield gas turbine power plants under the aegis of the NIPP. The arrangement is to establish power plants in the Niger-Delta to buy in the people and assuage their feelings of neglect and deprivation of the area. In the Niger-Delta compensatory formula, additional seven gas turbine plants would be located as follow: $225 \mathrm{mw}$ plant in Gbaran, Bayelsa State; $451 \mathrm{mw}$ plant in Ihovbor, Edo State; $230 \mathrm{mw}$ plant in Omoku, Rivers State; 451mw plant in Sapele, Delta State; 338mw plant in Egbema, Imo State; 561 mw plant in Calabar, Cross River State; and 188mw plant in Ibom, Akwa Ibom State (Igbikiowubo, 2007). Thus, the NIPP was designed, as a fast-track project, to improving Nigeria's electric power supply through the improvement of generation, transmission and distribution and gas supply supports.

The then Managing Director of Nigeria Gas Company, Chris Ogiemwonyi, assured Nigerians that while all the power plants would be adequately supplied with gas, the issue of price differential was being tackled. Stating that NGC has more of its gas supply from Utorogu/Oben as well as offshore line, he maintained: "We are ready to supply all the IPP plants and we are expanding our sources of gas supply" (Lawal, 2007). These foregoing informed the logic of the powerprobe in Nigeria.

The Obasanjo administration's posturing at its terminal stage conveyed remarkable sense of buck-passing and anxiety that made Yar'Adua to adopt tactics of absolving his administration from blame of huge expenditure that failed to revamp the power sector. As logic would permit, the NERC's shoddy case was just the tip of the ice-berg as the House of Representatives mandated its Committee on Power and Steel to carry out a comprehensive investigation of money spent by the Obasanjo administration between May 1999 and June 2007 in the guise of revamping the ailing electricity sector and, therefrom, ascertain why the situation has not improved (Ogbodo \& Yakubu, 2008).

The power probe was necessitated more by the revelation made by the late President Yar'Adua as quoted in Ogbodo and Yakubu (2008) stating: "over \$10bn was said to have been spent on the power sector by the last administration, but not with commensurate results." The Chairman of the House Committee, Ndudi Elumelu revealed that between \$10bn and \$16bn was involved, out of which \$12.93bn had been tracked (Usigbe, 2008). The money included local and international sources. According to the House Committee, the money was expended through $\$ 40 \mathrm{~m}$ received by the Ministry of Energy; $\$ 3.2 \mathrm{bn}$ given to PHCN; $\$ 3.07 \mathrm{bn}$ for the NIPP; $\$ 500 \mathrm{~m}$ to REA; \$10m given to the Energy Commission of Nigeria (ECN); \$460m loans from World Bank and other agencies; $\$ 4.06 \mathrm{bn}$ internally-generated revenue from PHCN and \$1.62bn from NNPC Contributory Funds and Joint Venture on power plants.

The revelation by the probe committee generated controversy between the Lower House and the Federal Government. Defending government position on the allegation, the Minister of State for Power, Fatima Ibrahim, argued to the contrary that only $\$ 10 \mathrm{bn}$, and not $\$ 16 \mathrm{bn}$ as alleged by the House, was actually spent on the power sector within the period. But the House position was that the $\$ 10 \mathrm{bn}$ spent by government did not include sums from international donor agencies and governments. The amount was spent on NIPP transmission infrastructure and National Rural Electrification Projects (Binniyat, 2008a).

The attempt by the House Committee to finger 21 highly-placed untouchables in Nigeria who were alleged to have perpetrated the power crisis was summarily dismissed. To close the matter, the accused used their political positions in somewhat framed-up charges to force the Chairman of the probe committee into political limbo that finally hid the orchestra from public glare of political scrutiny (Abimboye \& Agbaegbu, 2009). Binniyat (2009) argued:

The most interesting thing is that Elumelu tried to bring out the likely thieves and, he made a great show of it. He became the most celebrated lawmaker in the land. He was a lead story material for stories that sold him as a hero of the people. But incongruously, today, Elumelu and others are standing trial for allegedly stealing N5.4bn meant for Rural Electrification Agency on a 56-count charge brought on him and Chairman of the Senate Committee on Power, Senator Nicholas Ugbane... If the EFCC is able to prove that indeed Elumelu is involved in this alleged grand conspiracy to steal N5.4bn meant for power infrastructure in rural areas, it would amount to such a betrayal of trust, such a monumental insult on the collective psyche of Nigerians that no one in position of authority can be trusted in Nigeria again... 
Truly, Nigeria's leaders have always walked the tight rope when it comes to transparency, accountability and probity that they are hardly trusted in the management of public affairs. Before the ordeal of Elumelu over the power probe, his Committee's Report of May 2008, revealed:

...the Committee found that over $\$ 13 \mathrm{bn}$ was expended on the power sector in eight years while commitments that were not funded amounted to $\$ 12 \mathrm{bn}$. Had the supplementary budget of the power sector in 2007 been implemented, the expenditure could then have been over $\$ 16 \mathrm{bn}$ as reported by the Honourable Speaker of the House.

That report indicated that apart from expenditure above $\$ 13 \mathrm{~b}$ as tracked by the Committee, Nigeria is placed on debt list to the tune of another $\$ 12 b$, showing that the administration had expended over $\$ 25 \mathrm{~b}$ on the power sector, of which Nigeria should either fund the unfunded commitments or cancel them. The related issues of transparency and accountability question the integrity and political will of Nigeria's leadership to tackle the deplorable situation of the power sector following the mind-boggling discoveries in the report of the House Committee that investigated activities in the sector (Newswatch, 2009). Sadly enough, political interest in the matter compelled the report to gather dust where it had been jettisoned after 84 of the 88 recommendations were dropped by a 7-man House of Representatives Review Committee (Ige \& Binniyat, 2009). The result was that the huge sums were lost and Nigeria goes cap-in-hand for internal and international financial assistance from the World Bank, African Development Bank, Central Bank of Nigeria with its consequences for national development.

Outside financial grants from other organizations, record has it that the World Bank between 2003 and 2007 alone, gave Nigeria \$272m; added to the figure from 1999 to part of 2003, the total sum from World Bank alone came to N299bn as energy development package aimed at enhancing two critical areas of transmission project development and energy development project. The two projects, confirmed by the PHCN System Coordinator, Shuaibu Maigida, are "to serve as interventions for achieving the World Bank mission of global poverty reduction and improvement of living standards...assisting in the enhancement of the transmission and distribution efficiency through investment in infrastructure and technical assistance" (Binniyat, 2007).

Beyond the World Bank-assisted fund already spent, as it were, in the power projects, the organization in 2009, gave Nigeria $\$ 600$ million soft credit to assist in revamping her power and gas infrastructure (Onuorah \& Okwe, 2008). The expectation was that the Nigeria Electricity and Gas Improvement Project (NEGIP) would provide for Partial Risk Guarantees (PRGs) in support of Gas Supply Agreements that would increase gas supply to boost power generation, transmission and distribution infrastructure and thereby relieve Nigeria of a critical problem for her economic growth and development.

Part of the challenges is the obvious negative conditionalities attached to loan-taking whereby policy-agenda are dictated for the recipient state. Out of the $\$ 600 \mathrm{~m}$, only $\$ 200 \mathrm{~m}$ was dedicated for the power sector, while $\$ 400 \mathrm{~m}$ was set aside for three other projects unrelated to power: HIVIAIDS $(\$ 226 \mathrm{~m})$; malaria booster $(\$ 100 \mathrm{~m})$; and Lagos Secondary Education Project $(\$ 95 \mathrm{~m})$. The diversionary policy implementation amply hinged on the condition of the loan as spelt out by the World Bank. The credit comprises $\$ 200 \mathrm{~m}$ in IDA credits to assist in network investments and technical assistance to improve electricity supply and another $\$ 400 \mathrm{~m}$ in PRGs in support of domestic gas market development. The inclusion of "PRGs" as a proviso in the loan package reveals how desperate need for infrastructural development loan in Nigeria accentuates dearth of funds through dubious and fraudulent agreements that boost capital flight under loan pay-back period.

There is no doubt that there are many challenges against the power sector reform. However, to achieve the national objectives, these challenges provide the opposite side of the coin that if adequately addressed will provide Nigeria with the prospects inherent in the sectoral reform.

\section{Prospects for Nigeria's Power Sector Reforms}

It is undeniable that Nigeria has many sources she can tap to generate the much-desired electricity for industrial activity and consequently promote economic development. These sources include the thermal (steam and gas), hydro, solar sources of energy generation. The steam source involves coal. Of all these sources, Nigeria has rivers and dams for hydro-power but that causes a fortune for construction and maintenance for a country that roams the international community with a begging bowl for development assistance. Yet, Nigeria has gas reserves that are unexploited and flared because of lack of technology and misplaced priority in the oil industry.

Considering the best alternative source of energy in the light of cost-benefit analysis of each of the sources available to Nigeria, one would suggest the cheaper sources of waste-to-energy as in Asian countries and coal energy as in South Africa with over $80 \%$ of its energy source from coal. Nigeria's electricity sources were primarily limited to two: hydro and thermal at the ratio of 1:3. The reasons are quite easy to glean. Nigeria's gas reserve has not been effectively 
harnessed for gainful power generation.

To stop the waste of natural resources to engineer the power sector, the deregulation policy of government for private participation and competition holds better prospects. The chances are that as many private firms as may be interested would invest capital, technology and expertise in varied degrees of power generation in the country; thus widening the operational scope by developing numerous sources of energy according to their comparative advantage in technical skills. Nigeria's reformed energy sector is expected to reap from her numerous resources. Nigeria under this demand too, would stop flaring of gas at daily loss of 1,100 million scf and financial loss of N5.8bn as was the case between October 2006 and July 2008. Gas flaring alone under the climate change regime has the attendant challenges of clean-up, remediation and rehabilitation which have long been ignored due to Nigeria's technological backwardness and lack of priority interest by government and international oil companies operating in the country. Thus, part of the energy supply trajectory will witness a system of clean-up through conversion process from gas into gainful utilisation in production of additional electricity.

Additionally, the coal reserve of about 2.75 billion metric tonnes, which is estimated at N10.5bn with enhanced production of 10 million tonnes annually also will be more acceptable to competing firms with the best-suited technology in the coal-related energy sub-sector to improve the contribution of coal to the nation's energy requirement, which had virtually fallen far below the 1991 record of $0.6 \%$ of 50 years ago, when the coal industry was in a good position with about one million metric tonne-production that fed the first set of industries in Nigeria (Oladejo, 1993). Part of the manifest evidence in rediscovering the coal resource is the effort by NERC through the National Assembly to adopt a five-year appropriate pricing regime that will boost coal production, marketing and consumption in Nigeria.

It is also expected that with private participation, more environmentally-friendly energy sources would be developed and promoted in the era of bio-fuels to engage the agricultural sector of the economy effectively. Nigeria's home of sugar-cane, and grain-based ethanol; and corn, wheat, soy beans and cassava, would be rewarding in advancing carbon-free bio-fuels than carbon-belching fossil fuels, like petroleum and gas.

The reform package steadily and surely will address the major disastrous consequences of external debt overhang as constraining factor on the development of Nigeria's infrastructures, especially in the power sector. A case in point is when the Nigerian government announced that it would require about N300bn to invest in the power sector between the years 2001 and 2003, but the mounting annual external debt repayment value of N150bn in the budget reduced provision for the power and steel ministry to a paltry N70bn in 2001 budget (Atojoko, 2000). Since paucity of fund promotes paucity of infrastructures, with transparency and public accountability, private participation in the sector will reduce public sector borrowing since respective participating firm will invest enormous capital in their business strategy to out-compete opponents and corner the marketplace. As a corollary, through competition, each firm will be best disposed with attractive service delivery to corner and control the widened consumer-market expected to expand into rural areas to the doorsteps of small and medium scale entrepreneurs that are emerging from there to make profit and stay on business. Greater competition in the power industry will engender tariff regime based on market forces, efficiency gain through price equity and technological transfer into Nigeria from the Western technological giants.

Thus, analysts like Adenikinju (cited in Nwachukwu, 2013) have concluded that the power sector reforms against the background of institutional, legal, regulatory and capital challenges and prospects of efficient and competitive operation of the power sector in Nigeria was found to hold great promise as a special case of clear policy decision to boost Nigeria's social and economic development. He noted that lack of political will to see reforms through due to varied private-regarding interests have been used to either slow down the processes or reverse them completely; alienation of Nigerians and other stakeholders from the reforms, leading to resistance in implementation, especially the power privatization, deregulation of the downstream and passage of the Petroleum Industry Bill (PIB); intra-government conflicts with opposing interests in the process working to undermine one another's interests, which have kept the PIB in the National Assembly for over ten years despite being touted as the best thing to happen to the energy sector if and when allowed to see the light of day. These are indicative that the reforms may not have the full support of those in government's top hierarchy. It brought about policy swings and disruptions of timelines leading to credibility gaps among investors and target misses and loss of confidence in the process; as well as lack of sanctions for missing targets has ensured continuous policy somersaults and lack of commitment to set targets, notwithstanding the institution of performance bonds by the current administration.

\section{Conclusion and Recommendations}

The policy direction on the power sector in Nigeria should be matched with increased political will, leadership transparency and accountability to achieve maximum success. In addition, Nigeria should put in place effective energy 
conservation laws to spell out energy-waste sanctions and penalties to deter offenders and violators and, by extension, do away with the perception of government's utilities as nobody's business. Nigeria should mobilize and improve on vocational skills of her available human resources and expand the exploitation of her natural resources in the power sector by involving independent power operators; she should adopt the requisite attitudes of best practices, cost-saving strategies for the efficient utilisation of energy. Indeed, Nigeria's sustainable energy trajectory must, as a current necessity in the fast integrating global system, be conscious of the "Bali Roadmap" on the Kyoto Protocol by the 186 United Nations-member states passed under the auspices of the United Nations Framework Convention on Climate Change in December 2007.

Nigeria's improved power generation and supply will have the potential of conserving fuel and funds used in powering generating sets in the country witht the attendant health implications for the citizens. The imperativeness of a conversion process from waste to wealth provides a strong leeway because the energy saved is additional energy produced. Should Nigeria brace up to the challenges confronting the power sector, she would have certainly created the enabling environment towards attaining social and economic development of her peoples.

Focusing on simultaneous power generation in each state could help speed up the provision of adequate power across the country; that is to say, it would make sense to build $10 \mathrm{mw}$ of power in one locality instead of one power plant of $1000 \mathrm{mw}$ that would take years to build and which would put the entire populace in turmoil if anything happens to it. The present unbundling of the PHCN into different companies under the privatization programme, which has seen President Jonathan commissioning the different companies in various parts of the country, is a pointer to the gains that Nigeria would make if it is sustained.

The new investors, according to Price Waterhouse Coopers (2013) are responsible for operating the power companies and making the necessary investments to improve distribution networks and generation in line with the Federal Government's objective of improving the country's power supply which is only at about 4,000mw presently to a population of over 160 million. The new owners of the companies are supposed to show good faith by ensuring that the difference they are supposed to make is felt immediately; and the people must feel that it was the best policy option to disaggregate the omnibus PHCN for greater service delivery. It is noteworthy to mention that then Minister of Power, Chinedu Nebo, in an interview in Channels Television on 2 November 2013, noted that within the next one and half years, most Nigerians would have uninterrupted power supply. Unfortunately, as at the time of concluding this study, the reverse has been the case, as the power supply in Nigeria has dovetailed to a terrible low since the turn of the year 2015, and the Jonathan administration has left Nigeria in the dark as his government wound down. As at 26 May 2015, just a few days to the end of the Jonathan tenure of office, only 5 out of 23 power plants were generating electricity as the government claimed that the nation had recorded a loss of over $2,000 \mathrm{mw}$ in the national grid due to shortage of gas supply to the thermal plants.

In conclusion, therefore, if there is effective and efficient management of power supply, there will be increased industrialisation, private and public participation, job creation, high productivity under condition of security borne out of redirection of youthful energies into productive forces to bring about national development. Anything short of this is a waste of resources in the name of reforms.

\section{References}

Abimboye, D. \& Agbaegbu, T. (2009). 20 persons to blame for Nigeria's power crisis. Newswatch, March 9.

Agbaegbu, T. \& Adzegeh, S. (2009). The looting at NERC. Newswatch, March 16.

Ahiuma-Young, V. (2009). N96bn government debt killing PHCN. Vanguard, July 31.

Akaeze, A. (2009). Counting their losses. Newswatch, March 16.

Akomolafe, F. (2013). My jet is bigger than yours. New African, No. 526, March.

Binniyat, L. (2007). World Bank's grant to Nigeria's energy sector hit N36.4bn. Vanguard, March 6.

Binniyat, L. (2008). Only \$10bn spent on power sector from 1999 to 2007. Vanguard, March 1.

Binniyat, L. (2009). N5.4 billion scam: Is Elumelu a victim of his own contrivance? Vanguard, May 15.

Ejumudo, T.F. \& Ejumudo, K.B.O. (2014). The operations of the Power Holding Company of Nigeria and discriminatory monopoly. Journal of Energy Technologies and Policy, 4(6):60-68. http://www.iiste.org/Journals/index.php/JETP larticle/download/13826/14000

Ekwujuru, P. (2007). Nigeria needs \$60bn to tackle power outage. Vanguard, March 7.

Ezeani, E.O. (2008). The state and crisis in the power sector in Nigeria. University of Nigeria Journal of Political Economy, 2(1\&2):1-21.

Federal Republic of Nigeria (2005). Electric Power Sector Reform Act. Official Gazette, No. 77, Vol. 92, 8th August. http://www.power.gov.ng/download/Electric\%20Power\%20Sector\%20Reform\%20Act\%202005.pdf

Federal Ministry of Information (n.d.). The Obasanjo Reforms: Electric Power Sector. Abuja: FMI.

Igbikiowubo, H. (2007). Nigerians contend with darkness 8 years after. Vanguard, April 4. 
Ige, I. \& Binniyat, L. (2009). Power probe: Reps dump Elumelu's report. Vanguard, May 15.

Nwachukwu, C. (2013). Energy sector reforms stagnated - Experts. Vanguard, 17 April. http://www.vanguardngr.com/2013/04/energysector-reforms-stagnated-experts/

Obasi, S. (2009). An unrealisable target. Newswatch, November 23.

Ochayi, C. (2015). Electricity supply down by 2,000mw - FG. Vanguard, 26 May. http://www.vanguardngr.com/2015/05/electricitysupply-down-by-2000mw-says-fg/

Ofikhenua, J. (2012). Power generation still 4,439.5mw. The Nation, 12 September.

Ogbodo, J.A. \& Lawal, Y. (2008). Reps probe \$10b spending on power projects. The Guardian, February 1.

Oke, I. (2010). Nigeria and the imperative of power reform. The Nation, August 23.

Okigbo, P. (1986). Towards a reconstruction of the political economy of Igbo civilisation. Ahiajoku Lecture. Owerri: Ministry of Information, Culture, Youth and Sports.

Okoro, O.I., Govenda, P. \& Chikuni, E. (2006). Power sector reforms in Nigeria: Opportunities and challenges". Proceedings of 14th International Conference on Domestic Use of Energy. Cape Town: South Africa.

Okpugie, G. (2009). Experts advise on efficient use of electricity ahead of 6,000mw in December. The Guardian, November 15.

Olajide, B. (2008). Power sector hiccups: IMF throws hat into the ring. The Guardian, September 3.

Oloja, M. (2009). Tussle over N177.95bn cripples power sector revival. The Guardian, March 1.

Price Waterhouse Coopers (2013). Privatization in the power sector: Navigating the transition. https://www.pwc.com/en_NG/ng/assets/pdf/pwc-round-table-post-privatisation.pdf

Salau, S. (2010). Why Nigeria's huge gas reserves failed to deliver local market. The Guardian, July 7.

Salem, T. (2010). Electricity fund: Oil companies to pay $2 \%$ profit. Vanguard, May 3.

The Guardian (1993). Government releases 10-year plan for nuclear energy. The Guardian, December 4.

The Guardian (2001). New power projects in West Africa to gulp \$10b. The Guardian, October 3.

The Guardian (2013). As power remains a problem. The Guardian Editorial, Monday, 24th June.

Ukpevo, G. (1993). Energy: Never expect power always. Newswatch, April 5.

United Nations (1965). The role and the application of electric power in the industrialization of Asia and the Far East, New York: United Nations.

Usigbe, L. (2008). Reps committee track down N13bn power funds. Vanguard, March 10.

Vanguard Editorial (2002). NITEL privatisation: Time to pause; time to start afresh. Vanguard, March 25.

Vanguard (2013). FG dissolves PHCN, pays workers N360bn. Vanguard, November 02. http://www.vanguardngr.com/2013/11/fgdissolves-phon-pays-workers-n360bn/

Yakubu, L. (2007). National electricity generation hits 3,300mw. The Guardian, April 23.

Yakubu, L. \& Ebosele, Y. (2008). A new vision for the power sector. The Guardian, July 21. 